NBER WORKING PAPER SERIES

\begin{abstract}
A MODEL OF TRADE AND EXCHANGE RATE
PROJECTIONS: EQUATIONS AND PARAMETERS
\end{abstract}

Hannu Halttunen

Dennis Warner

Working Paper No. 390

\author{
NATIONAL BUREAU OF ECONOMIC RESEARCH \\ 1050 Massachusetts Avenue \\ Cambridge MA 02138
}

August 1979

\begin{abstract}
The models presented in this paper were developed by the authors under the direction of William Branson while at OECD Project Interfutures and were extended during the NBER Summer Institute for International Economics. The results of the simulations are somewhat different from those contained in the final report of Project Interfutures and do not reflect the official views of Project Interfutures. The research reported here is part of the NBER's research program in International Studies. Any opinions expressed are those of the authors and not those of the National Bureau of Economic Research.
\end{abstract}




\title{
A Model of Trade and Exchange Rate Projections: \\ Equations and Parameters
}

\author{
ABSTRACT
}

Thls paper contalns a detalled description of a model of trade and exchange rates. A verbal summary of the model may be found in NBER Working Paper \#389.

The model contains equations for Import demands, bllateral trade flows and trade prices for 26 reglons and three commoditles. A simple exchange rate model used developments in current accounts to model changes in nominal exchange rates. The regions covered are the twenty-three ${ }^{1}$ OECD countrles and three non-OECD reglon: LDCs, OPEC, and the centrally planned economies (CPEs).

Sector A contalns an algebralc description of the model and a glossary of varlables and parameters. Section $B$ is a detalled discussion of the equations and the sources of the parameter values.

Hannu Halttunen

Pank of Finland

Research Department

P.0. Box 160

SF-00101 Helsink1

FINLAVID
Dennis Warner

Department of Economics Michlgan State UnIversity E. Lansing, MI 48824

$517 / 355-7756$

\footnotetext{
${ }^{1}$ Belglum and Luxembourg are comblned and Yugoslavia is Included in the $\mathrm{CPE}$ region.
} 


\section{Introduction}

This paper contains a detailed description of a model of trade and exchange rates. A verbal summary of the model may be found in NBER Working Paper \#

The model contains equations for import demands, bilateral trade flows and trade prices for 26 regions and three commodities. A simple exchange rate model used developments in current accounts to model changes in nominal exchange rates. The regions covered are the twenty-three ${ }^{1}$ OECD countries and three non-OECD regions: LDCs, OPEC, and the centra11y planned economies (CPEs). Sector A contains an algebraic description of the model and a glossary of variables and parameters. Section $B$ is a detailed discussion of the equations and the sources of the parameter values.

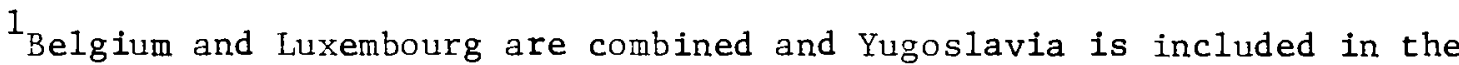
CPE region.
} 


\section{A. Equatlons of the Trade \& Exchange Rate Model}

1. Trade Flows - Imports

a. OECD country Imports of goods and services:

$$
\mathrm{MGS}_{1}=P_{1} Y_{1}\left[\left(\frac{Y_{1}}{Y_{1}^{*}}\right)^{\alpha_{1}}\left(\frac{P_{1}}{\text { PMGS }_{1}}\right)^{\beta_{1}}\right]
$$

b. IDC Imports of goods and services and petroleum*: $\hat{M G S P}_{L D C}=\hat{\beta}_{L D C}\left(\hat{P D}_{L D C}-\hat{P M G S P}_{L D C}\right)+\alpha_{L D C}\left(\hat{\bar{Y}}_{L D C}\right)$

c. OPEC Imports of goods and services and petroleum: $\hat{M G S P}_{\text {OPEC }}=$ exogenous

d. CPES Imports of goods and services and petroleum:

$$
\text { MGSP }_{\text {CPES }}=\frac{\text { REV }_{\text {CPES }}}{\text { PMGSP }_{\text {CPE }}}
$$

e. Goods, services for $\mathrm{OECD}$ countries $(1=1,23)$ :

$$
\begin{aligned}
& M G_{1}=\left(1-Y_{1}\right) M S_{1} \\
& M S_{1}=Y_{1} M S_{1}
\end{aligned}
$$

f. Goods, services, petroleum for Non-OECD reglons $(1=24,26)$

$$
\begin{aligned}
& M G_{1}=\left(1-Y_{1}-\phi_{1}\right) M_{1} P_{1} \\
& M S_{1}=Y_{1} \operatorname{MGSP}_{1} \\
& M P_{1}=\phi_{1} \text { MGSP }_{1}
\end{aligned}
$$


8. Petroleum imports for OECD regions

$$
\hat{\mathrm{MP}}_{1}=\hat{K}_{1} \mu_{1}\left(\hat{\mathrm{PD}}_{1}-\hat{\mathrm{PMP}}_{1}\right)+\left(1-\kappa_{1}\right)\left(\hat{\mathrm{MP}}_{1, t-1}-\varepsilon_{1} \hat{\mathrm{Y}}_{1, t-1}\right)+\varepsilon ; \hat{\mathrm{Y}}
$$

2. Trade Flows - Bxports

$$
\begin{aligned}
& \text { a. } X G_{1}=\sum_{j} \mathrm{H}_{j 1} M G_{j} \\
& \text { b. } X S_{1}=\delta_{1 j} \sum_{j} S_{j} \\
& \text { c. } X P_{1}=\sum_{j} \Gamma_{j 1} M P_{j}
\end{aligned}
$$

3. Trade-Share Equations

$$
\begin{aligned}
& \text { a. } \hat{\mathrm{H}}_{1 f}=\lambda_{1 f}\left(\hat{P X G_{j}}-\hat{P M G}_{1}\right)+\eta_{1 j}\left(\hat{Y}_{j}-\sum_{k} \mathrm{H}_{1 j, t-1} \hat{Y}_{k}\right) \\
& \text { b. } \hat{\delta}_{1}=\lambda_{s}\left(P \hat{X S}_{1}-\sum_{k} P \hat{X S}_{1} \delta_{k, t-1}\right)+\eta_{s_{1}}\left(\hat{Y}_{1}-\sum_{k} \delta_{k, t-1} \cdot \hat{Y}_{k}\right)
\end{aligned}
$$

4. Price Equations

$$
\begin{aligned}
& \text { a. } \hat{P X G_{1}}=\omega_{1} \hat{P W G}_{1}+\left(1-w_{1}\right) \hat{P D}_{1} \\
& \text { b. } P X S_{1}=\omega_{1} \hat{P W S}_{1}+\left(1-\omega_{1}\right) \hat{P D}_{1} \\
& \text { c. } P M G_{1}=\sum_{j} \mathrm{H}_{1 j} \mathrm{PXG}_{\mathrm{f}} \\
& \text { d. } \text { PMS }_{1}=\sum_{j} \delta_{j} \text { PXS }_{j} \\
& \text { e. } P M P_{1}=\sum_{j} \Gamma_{I j} P X P_{j} \\
& \text { f. PMGS }=\gamma_{1} \text { PMS }_{1}+\left(1-\gamma_{1}\right) \text { PMG } 1 \quad 1=1, \ldots, 23 \\
& \text { g. PMGSP }=\gamma_{1} \text { PMS }_{1}+\text { PMP }_{1}+\left(1-\gamma_{1}-\emptyset\right) \text { PMG }_{1} \quad 1=24, \ldots, 26
\end{aligned}
$$


$-3-$

h. $P W G_{1}=\sum_{j} \Omega_{1 j} \sum H_{j k} P X G_{K}$

5. Other Parts of Current Account and Asset Accumulation

a. Net investment Income:

$$
R_{1}=r_{1} s_{1, t-1}
$$

b. Ald for IDC:

$$
\begin{aligned}
G_{L C D} & =\bar{G}_{L D C} \\
\text { for } D E C D: & G_{1}=G_{L D C} \cdot \frac{G_{1, t-1}}{G_{L D C^{\prime} t-1}}
\end{aligned}
$$

c. Other items in the current account:

$$
z_{1}=\bar{z}_{1}
$$

d. Current account:

$$
\begin{aligned}
C_{1}= & \mathrm{PXG}_{1} \cdot \mathrm{XG_{1 }}+\mathrm{PXS}_{1} \cdot \mathrm{XS}_{1}+\mathrm{PXP}_{1} \cdot \mathrm{XP}_{1} \\
& -\mathrm{PMG}_{1} \cdot \mathrm{MG}_{1}-\mathrm{PMS}_{1} \cdot \mathrm{MS}_{1}-\mathrm{PMP}_{1} \cdot \mathrm{MP}_{1} \\
& +\mathrm{G}_{1}+\mathrm{Z}_{1}+\mathrm{R}_{1}
\end{aligned}
$$

s

e. NET foreign assets:

$$
\begin{aligned}
& \text { Total: } F_{1}=F_{I_{t-1}}+C_{1}: \\
& \text { Accumulated since 1975: } S_{1}=S_{1_{t-1}}+C_{1} .
\end{aligned}
$$

f. Revenue:

$$
\mathrm{REV}_{1}=\mathrm{C}_{1}+\mathrm{PMG}_{1} \cdot \mathrm{MG}_{1}+\mathrm{PMS}_{1} \cdot \mathrm{MS}_{1}+\mathrm{PMP}_{1} \cdot \mathrm{MP} \mathrm{P}_{1}
$$


6. Domestic Price

$$
\hat{P D}_{1}=\pi_{1} \hat{P M P}_{1}+\phi_{1} \hat{P M G S}_{i}+\left(1-\pi_{1}-\psi_{1}\right) \hat{\mathrm{E}}_{i}
$$

\section{Exchange Rate Equations}

a. Exchange rate float equations for 6 major $\mathrm{ORCD}$ countries:

$$
\begin{aligned}
\Delta E_{1}=\xi_{1} \Delta F_{1}+o_{1} \Delta F_{f} ; \text { where } f & =\text { Germany } \\
\text { and } 1 & =U R, \text { FRANCE, ITALY: } \\
\text { or } f & =U S \\
\text { and } 1 & =\text { Canada, Japan, Germany }
\end{aligned}
$$

b. Frachange rate basket rule for small countrles and IDC:

- Det $T$ be the total trade weights, 1.e.:

$$
T_{1 f}=\frac{\text { Bxports from } 1 \text { to } f+\text { Pxports from } f \text { to } 1 .}{\text { Exports of } 1+\text { Imports of } 1}
$$

Let $1=1, \ldots . \mathrm{S}$ Index the 17 small countries;

$f=s+1, \ldots . B$ Index the 7 major OECD countrles, OPEC and CPEs.

-Let TSS be the SXS upper left submatrix of $T$, and

TSB be the SX(B-S) upper right submatrix of $T$, and

$e_{1}-\frac{E_{1}}{E_{1 / 5}}$

$e_{s}$ the $s$ element vector of small country exchange rate incides.

$e_{B}$ the (B-S) element vector of large country exchange rate indices.

$k_{s}$ a $s \times s$ diagonal matrix of parameters.

Then,

$e_{8}=k_{B}\left[\begin{array}{ll}T_{S B} & T_{8 B}\end{array}\right]$;

which gives after expansion of terms:

$e_{s}=k_{s} T_{s 8} e_{s}+k_{s} T_{s B} e_{B}$. 
Therefore, the reduced form for the $S$ exchange rates is:

$e_{8}=k_{8}\left[I-T_{88}\right]^{-1} T_{8 B} e_{B}$

Note: $k_{1}$ is the basket target index, 1.e., if $e_{1}$ 1s to be pegged to a basket $k_{1}=1$; and if $e_{1}$ is to respond to current account inbalances $k_{1}=k_{1-1}+\theta \frac{c_{1, t-1}}{R E V_{1, t-1}}$.

c. Change of parameters if exchange rate changes in prevlous period:

- Let $R R_{1}=1-\left|\hat{E}_{1}\right|$

$$
\mathrm{RS}_{1}=1-\left|\hat{\mathrm{E}}_{\mathrm{t}-1}\right|
$$

Then,

$$
k_{1}=k_{1, t-1}+\theta \cdot \frac{R R}{R S} \cdot \frac{C_{i, t-1}}{R E V_{i, t-1}}
$$




\section{Trade Flows}

$\begin{array}{ll}\text { XG } & \text { Exports of Goods billions of } 1975 \$ \\ \text { XS } & \text { Exports of Non-Factor Services bilifons of } 1975 \$ \\ \text { XP } & \text { Exports of Petroleum (SITC 331) billions of } 1975 \$ \\ \text { MGS } & \text { Imports of Goods \& Non-Pactor Services billions of } 1975 \$ \\ \text { MG } & \text { Imports of Goods billions of } 1975 \$ \\ \text { MS } & \text { Imports of Non-Factor Services bilifons of } 1975 \$ \\ \text { MP } & \text { Imports of Petroleum (SITC 331) billions of } 1975 \$\end{array}$

$\underline{\text { Prices }}$

$\begin{array}{ll}\text { E } & \text { \$/Local Exchange Rate } 1975=1 \\ \text { PD } & \text { Domestic GDP-Deflator in } \$ 1975=1 \\ \text { PXG } & \text { Export of Goods Deflator in } \$ 1975=1 \\ \text { PXS } & \text { Export of Non-Factor Services Deflator in } \$ 1975=1 \\ \text { PXP } & \text { Export of Petroleum Deflator in } \$ 1975=1 \\ \text { PMGS } & \text { Import of Goods Non-Factor Services Deflator in } \$ 1975=1 \\ \text { PMG } & \text { Import of Goods in } \$ 1975=1 \\ \text { PMS } & \text { Import of Non-Factor Services in } \$ 1975=1 \\ \text { PMP } & \text { Import of Petroleum in } \$ 1975=1 \\ \text { PWG } & \text { Index of Competitor's goods export prices in } \$ 1975=1\end{array}$

Other Ourrent Account Items

C Balance on Current Account billions of $\$$

G Net Official arrent Transfers billions of $\$$

$\mathrm{Z} \quad$ Other Items in the current account billions of $\$$

(Net labor income, errors \& omissions, net private

transfers, Initial level of net investment income)

$R_{i} \quad$ Investment income billions of $\$$

REV Revenue from foreign activity billions of $\$$

Capital Account Items

F Net Foreign Assets billions of $\$$
$S \quad$ Net Foreign Assets billions of $\$$, accumulated since
beginning of stmulation

output

Y CDP, billions of 1975 U.S. \$

$Y^{*} \quad$ GDP at full-employment, billions of 1975 U.S. $\$$ 
PARAMETERS--

\section{Import Bquat1ons}

$\alpha_{1}$ Blasticity of non-011 goods and non-factor services (MGS) with respect to ratio of actual to potential GDP.

$B_{1}$ Blasticity of MGS with respect to the ratio of domestic prices to Import prices.

$p_{1}$ Constant term in MGS equation.

$r_{1}$ Share of imports of non-factor services (MS) in MGS (For 3 nonOBCD regions. This 18 share of US in (MG + MS + MP).

1 Share of imports of petroleum in total imports for non-OBCD reglons.

$K_{i} \quad$ Speed of adjustment in ofl import equation.

$\mu_{i}$ Relative price elasticity of oll Import demand.

$\varepsilon_{i} \quad$ Income elasticity of ofl import demand.

\section{Trade Shares}

$H_{1 j}$ Region f's share of region 1 's non-oll goods imports.

$\delta_{1}$ Region 1's share of total world exports of non-factor services.

$\Gamma_{1 j}$ Region f's share of region 1's petroleum imports.

$\boldsymbol{\Omega}_{1 j}$. Region f's share of region 1 's non-oll goods exports.

$\lambda_{1 j}$ Price elasticity of substitution for region f's goods in region 1 's market.

$n_{1 j}$ Income elasticity of substitution for reglon f's goods in region $1^{\prime}$ 's market.

$\lambda s_{1}$ Price elasticity for region $1^{\prime} \mathrm{s}$ service exports.

${ }^{n s_{1}}$ Income elasticity for region 1 's service exports.

\section{Price Equations}

$\pi_{i}$ Blasticlty of PD with respect to PMP.

$\psi_{i}$ Elasticity of PD with respect to PMGS.

$w_{i}$ Elasticity of PXG and PXS with respect to PWG and FWS.

\section{Ixchange Rate Sygtem}

$\xi_{i}$ Coefficlent on change in own net forelgn assets in exchange-

${ }_{i}$ Coefficlent on change in other region net forelgn assets in exchange-rate equation. 
B. Parameters of the Trade and Exchange Rate Model and The1r Sources

\section{Import Equations}

The short-run income elasticity in import equation for goods and services is $(\alpha)$ and the price elasticity is $(\beta)$. In the long-run, when $(Y)$ equals full-employment output $\left(Y^{*}\right)$ income elasticity is one and the long-term import/output ratio is (P) when relative prices remain stable.

Several estimates for the parameters $\alpha$ and $B$ are avallable in the literature for different countries. Most comprehensive sources are Basev1 (1973), Branson (1972), Houthakker-Magee (1969), Samue1son (1973), and Taplin (1973). Moreover, Stern, Francls and Schummacher (1977) provide an excellent survey of literature concerning price elasticities. $1 /$ These are the main sources for our purposes; especially the Taplin estimates were extensively explofted. Table 1 gives the estimates we have used in our model, which come mainly from Taplin's study. We wanted to exploft one common source as much as possible to guarantee the internal consistency of the parameter egtimates.

In the petroleum import equations the income elasticity $(\varepsilon)$, the price elasticity $(\mu)$ and the speed of adjustment $(k)$ are "guesstimates" based on Interfutures energy scenerto and they reflect assumptions of a decreased share of petroleum in the world energy balance and the ranking of regions according to their substitution possibilities. These are shown in Table 2. The service share of imports ( $\gamma$ ) is taken to be the 1975 value. 1975 data were also used to derive the constant terms $(P)$ and $(\phi)$ in the Import equations for goods and services and for petroleum respectively.

1/ The recent IMF Norld Trade Model by Deppler and RIpley (1978) was not avallable at the time when the survey of trade elasticities was carrled out. 


\begin{tabular}{|c|c|c|c|}
\hline & & $\alpha$ & $\beta$ \\
\hline 1. & Australia & 2.12 & 0.42 \\
\hline 2. & Aust ria & 2.04 & 0.95 \\
\hline 3. & Belgiun-Luxembourg & 2.27 & 0.65 \\
\hline 4. & Canada & 2.18 & 1.59 \\
\hline 5. & Denmark & 2.08 & 0.85 \\
\hline 6. & Finland & 2.02 & 0.50 \\
\hline 7. & Prance & 2.30 & 0.39 \\
\hline 8. & Germany & 2.35 & 0.60 \\
\hline 9. & Iceland & 2.13 & 0.06 \\
\hline 10. & Ireland & 1.96 & 2.40 \\
\hline 11 . & Italy & 1.26 & 1.03 \\
\hline 12. & Japan & 2.12 & 0.81 \\
\hline 13. & The Nether lands & 2.27 & 0.02 \\
\hline 14. & Norway & 1.90 & 1.20 \\
\hline 15. & Portugal & 1.86 & 0.40 \\
\hline 16. & Spain & 2.48 & 1.55 \\
\hline 17. & Sweden & 2.02 & 0.76 \\
\hline 18. & Switzerland & 2.25 & 1.10 \\
\hline 19. & Onited Ringdom & 2.24 & 0.22 \\
\hline 20. & United States & 2.81 & 1.05 \\
\hline 21. & Greece & 1.80 & 1.47 \\
\hline 22. & New Zealand & 2.00 & 1.12 \\
\hline 23. & Turkey & 2.29 & 0.65 \\
\hline 24. & Non-o11 LDCs & 1.00 & 0.70 \\
\hline 25. & OPEC & 1.00 & 0.70 \\
\hline 26. & Centrally Planned Economies & 1.00 & 0.70 \\
\hline
\end{tabular}

Source: Price elasticity B: Taplin (1973) except for Australla which 1s from Samuelson (1973). Income elasticity $\alpha$ : This is Taplin's activity elasticity plus one. It ghould be noted here that Taplin's activity varlable "autonomous expenditure", is an aggregate including government expenditure, gross fixed capital formation and exports of goods, and services. The activity varlable we use in our model $18 \mathrm{GDP}$. It may be the case with our income elasticity that it overpredicts the cyclical effect of income on imports. This should not, however, be a serfous drawback as we have constrained the long-term income elasticity to be unity. The income and price elasticitles for non-OECD reglons are set to one and .70 respectively. 


$\begin{gathered}\text { Income } \\ \text { Elasticity }\end{gathered}$
$(\varepsilon) \quad \begin{gathered}\text { Price } \\ \text { Elasticity }\end{gathered}(\mu) \quad \begin{gathered}\text { Speed of } \\ \text { Adjustment }\end{gathered}$

1. Austral1a

.80

1.00

.80

2. Austria

.80

3. Belglum-Luxembourg

.80

.30

.23

4. Canada

.80

.30

.23

5. Denmark

.80

6. Finland

.80

7. France

.80

8. Germany

9. Iceland

10. Ireland

11. Italy

12. Japan

13. The Netherlands

14. Norway

15. Portugal

16. Spain

17. Sweden

18. Switzerland

19. infted Ringdon

20. United States

21. Greece

22. New Zesland

23. Turkey

24. Non-011 LDCs

25. OPEC

26. Centrally Planned Econonies
.80

.80

.80

.80

.80

.80

.80

.80

.80

.80

.80

.80

.80

.80

.80

.80

.80

.80

.80
1.00

.80

.30

.23

.30

.23

.30

.23

.30

.23

.30

.23

.23

.23

.70

.30

.23

.30

.80

1.00

.23

.30

.23

.30

.23

.30

.23

.30

.80

1.00

.70

1.40

.23

.30

.23

.30

.23

.30

.23

.30

.23

.30

.23

To disaggregate total volume of imports of OPEC, non-oil LCDs and Centrally Planned Zconomies into imports of goods, services and petroleum, 1975 shares were used. 
2. Trade Share Equations

The empirical estimates for trade share elasticities $(\lambda)$ was taken from Samuelson (1973) and is shown in Table 3. The trade share elasticities with respect to relative potential output growth rates for each region were set equal to one for each region.

TABLE 3: Trade Share Elasticities with respect to Relat1ve Prices

\begin{tabular}{|llll|}
\hline Market & $\Lambda_{j}$ & Market & $\Lambda_{\mathrm{J}}$ \\
\hline Australia & -1.58 & Norway & -1.39 \\
Austria & -0.31 & Portugal* & -1.94 \\
Belgium-Lurembourg & -1.04 & Spain & -0.83 \\
Canada & -1.79 & Sweden & -0.60 \\
Denmark & -1.33 & Switzerland & -1.39 \\
Finland & -1.67 & United Ringdom & -0.99 \\
France & -1.55 & Dnited States & -1.42 \\
Germany & -1.64 & Greece* & -1.94 \\
Iceland & -1.94 & New Zealand* & -1.94 \\
Ireland & -2.06 & Turkey* & -1.94 \\
Italy & -0.86 & Non-oil IDCs & -1.13 \\
Japan & -1.17 & OPEC & -1.13 \\
Netherlands & -0.82 & Centrally Planned & -1.13 \\
& & Econonies & \\
\hline
\end{tabular}

Source: Samuelson (1973) pp. 10-11. Samuelson reports only a compound estimate for "other OECD" including Iceland, Portugal, Greece, New Zealand and Turkey. This is used for the above countries and is shown by * in Table 2. The compound estimates for "non$O B C D "$ was used accordingly for non-oll LXCs, OPBC and centrally planned economies. 
The numerical values for $\left(\lambda_{s}\right)$ are 1975 service export share weighted averages of aubstitution elasticties for goods import share matrix (see Table 2). These were used due to unavallabllity of other empirical estimates. The import share approach could not be used for services because data for bilateral flows are not avallable. The 1975 market shares are shown in Table 4.

TABLE 4: World Trade Share of Services $\left(\delta_{1}\right)$ in the Year 1975

\begin{tabular}{|llll|}
\hline Market & $\delta_{1}$ & Market & $\delta_{1}$ \\
\hline Australla & .011 & Norway & .022 \\
Austrla & .023 & Portugal & .006 \\
Selgium-Luxembourg & .027 & Spain & .032 \\
Canada & .026 & Sweden & .013 \\
Denmark & .018 & Switzerland & .005 \\
Finland & .006 & United Ringdom & .092 \\
France & .063 & Jnited States & .158 \\
Germany & .083 & Greece & .004 \\
Iceland & .001 & New Zealand & .004 \\
Ireland & .004 & Turkey & .003 \\
Italy & .052 & Non-ofl LDCs & .102 \\
Japan & .050 & OPEC & .022 \\
The Netherlands & .042 & Centrally Planned & .042 \\
& & Economies & \\
\hline
\end{tabular}

Source: IMF, International Financial statistics.

The petroleum import share matrix is determined exogenousiy outside the model. The inftial matrix used in the projections is from the year 1975. It can be changed, according to different assumptions on petroleum exports in different simulation runs. 


\section{Export Price Equation}

One alternative to obtain estimates for the coefficlents in the export price equation would be to use substitution elasticities from our import share equation and price elasticities from our import equations (calculate a compound price elasticity for each exporting country from subst1tution elasticities $(\lambda)$ and price elasticities $(\beta)$ ) in the import function and obtain supply elasticitles frow other sources. As econometric information about trade supply elasticities is very scarce (the only relevant emplrical estimates for our purposes that we are aware of are those reported in Artus and Rhomberg (1973)) and they are the same for each country in their model, we have chosen another approach. In the 11terature there exist versions of the type of equation in our model. Those studies which we consider the most sultable for our purposes are Artus and Rhomberg (1973), Samuelson (1973), and Dornbusch and Krugman (1977). The elasticities of export prices with respect to competitors' price and some measure of the cost variable from the above sources are shown in Table 5. The coefficlents for these varlables do not necessarily sum to unity; we therefore calculated the "first state estimates" as arithmetic means, using the estimates in colums 1,2 and 3 for the coefficient of competitors' prices and estimates in colums 5, 6 and 7 for the coefficlent of domestic prices. Then these coefficlents were scaled to add up to one. These are our final est1mates for $(\omega)$ for OECD countries and they are shown in Table 6. Branson and Papaefstrattou (1978) calculated proxies for market power for a sample of 41 countries consisting of both developed and developing countries. They assumed that market power in any commodity is an increasing function of the country's share in world trade.

A comparison of the market power index for 15 developed countrles using our estimates (Australla, Austrla, Belglum, Canada, Denmark, France, Germany, Italy, Japan, Netherlands, Norway, Spaln, Sweden, The Unfted Kingdom and The Onlted States) shows that these are closely related. This dependence allowed us to derlve a value for $(1-w)$ for the export price equation of non-011 LDCs in our model which 1s .70. This same elasticity was also applied to the export price equations for goods and services of Centrally Planned gconomles and OPEC. 
TABLE 5: Coefficients of Export Price Equations from Different Sourceg

\begin{tabular}{|c|c|c|c|c|c|c|c|c|}
\hline \multirow[t]{2}{*}{ MARKET } & \multicolumn{3}{|c|}{ Domestic costs } & \multirow{2}{*}{$\begin{array}{c}\text { Average of } \\
(1)-(3) \\
4\end{array}$} & \multicolumn{3}{|c|}{$\begin{array}{l}\text { Competitors' } \\
\text { price }\end{array}$} & \multirow{2}{*}{$\begin{array}{c}\text { Average of } \\
(5)-(7) \\
8\end{array}$} \\
\hline & 1 & 2 & 3 & & 5 & 6 & 7 & \\
\hline Australla & .39 & & .57 & .48 & .00 & & .24 & .12 \\
\hline Austria & .00 & .35 & & .18 & .21 & .65 & & .43 \\
\hline Belgfum-Iuxembourg & .00 & .28 & & .14 & .78 & .72 & & .75 \\
\hline Canada & .67 & .34 & .71 & .57 & .00 & .66 & .29 & .32 \\
\hline Denmark & .36 & .31 & & .34 & .47 & .69 & & .58 \\
\hline Finland & .42 & & & .42 & .66 & & & .66 \\
\hline France & .42 & .57 & .28 & .42 & .59 & .43 & .72 & .58 \\
\hline Germany & .38 & .58 & .17 & .38 & .00 & .42 & .83 & .42 \\
\hline Iceland & .36 & & & .36 & .08 & & & .08 \\
\hline Ireland & .57 & & & .57 & .50 & & & .50 \\
\hline Italy & .00 & .49 & .25 & .25 & .80 & .57 & .75 & .69 \\
\hline Japan & .00 & .52 & .41 & .31 & .60 & .48 & .59 & .56 \\
\hline Netherlands & .15 & .30 & & .23 & .56 & .70 & & .63 \\
\hline Norway & .00 & .33 & & .17 & .96 & .67 & & .82 \\
\hline Portugal & .36 & & & .36 & .08 & & & .08 \\
\hline Spain & .56 & .42 & & .49 & .00 & .58 & & .29 \\
\hline Sweden & .39 & .36 & & .38 & .83 & .64 & & .74 \\
\hline Switzerland & 1.05 & .42 & & .74 & .00 & .58 & & .29 \\
\hline Thited Ringdon & .81 & .40 & .47 & .56 & .27 & .60 & .53 & .47 \\
\hline United States & .99 & .78 & .70 & .82 & .19 & .22 & .30 & .24 \\
\hline Greece & .36 & & & .36 & .08 & & & .08 \\
\hline New Zealand & .36 & & & .36 & .08 & & & .08 \\
\hline Turkey & .36 & & & .36 & .08 & & & .08 \\
\hline Non-o11 LDCs & & & & & & & & \\
\hline OPEC & & & & & & & & \\
\hline $\begin{array}{l}\text { Centrally Planned } \\
\text { Econ omies }\end{array}$ & & & & & & & & \\
\hline
\end{tabular}

a/ Sources: (1),(5), Samuelson (1973); (2), (6), Artus-Rhomberg (1973); (3), (7), Dornbusch-Rrugman (1977) except for Australia, which is derived from the Reserve Bank of Australla's Model's (Johnson-Butlin 1977) export price equation.

b/ Column (2) is taken from the simulation exercise reported in Artus and Rhomberg, and It shows the effects of a 10 per cent devaluation of a currency of each country on the export prices of a devaluing country. The column for domestic price coefficients is obtained simply by subtracting coefficients reported in the column (2) from unity. 
TABLE 6: Export Price Elasticlties with respect to Domestic Costs and Competitor's Prices

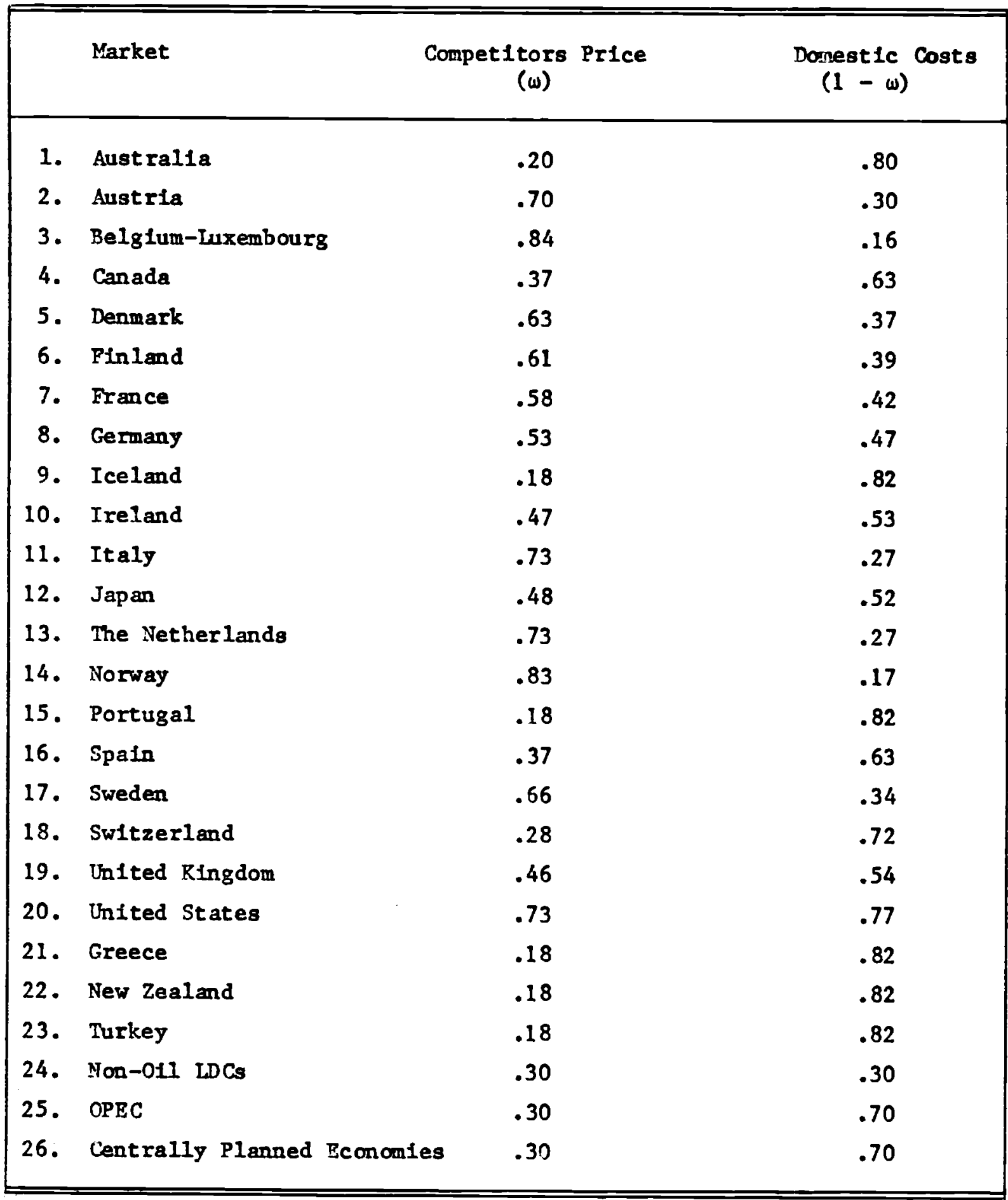

Source: See text. 
4. Other Parts of the Current Account

The "world interest rate" in the net investment income equation was set to .03. Inttial (1975) value for "other terms" in the current account is kept constant during the projection perlod.

5. Domestic Price Equation

The coeffictents for the effects of imported raw materlals $(\psi)$ and petroleum price increases $(\pi)$ are calculated according to the following formulas from the 1975 data and are shown in Table 7 .

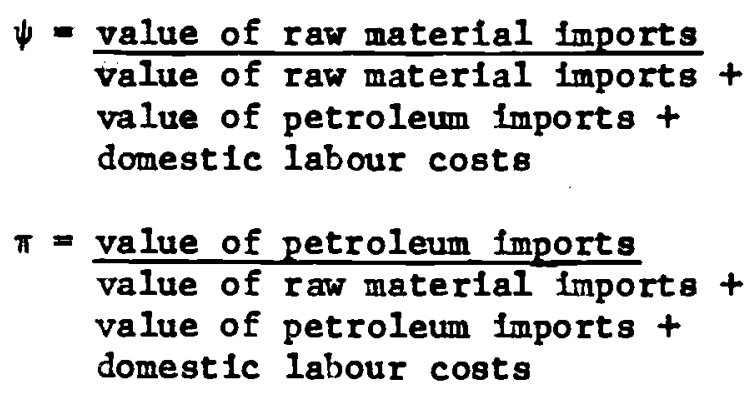

The following emplrical counterparts are used:

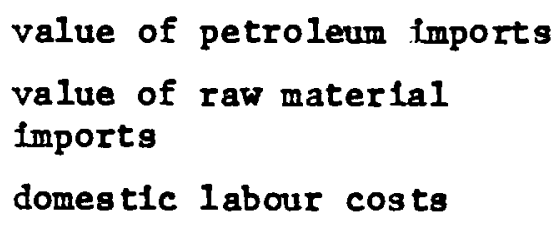

- SITC 331

$=\operatorname{SITC} 0+2+(3-331)+4+5+6$

- compensation of employees from the OECD's national income accounts

6. Exchange Rate Equations

For floaters exchange rate equations applying the asset market approach of exchange rate determination were obtained by linking the exchange rate equations estimated in Branson-Halttunen-Masson (1978) and in BransonHalttunen (1979) to the trade block. These sources give the exchange rate equations for Germany, Japan, the Unfted Ringdom, France, and Italy. The (dollar/local currency) exchange rates were used for the flrst two countries and for Canada $1 /$ and the (Deutsche Mark/local currency) rates for the three remaining countrles which were converted also to determine (dollar/local currency) exchange rates. The money stock variables in

$1 /$ Equation for $\left(\frac{\$ D S}{\$ C A}\right)$ exchange rate was estimated separately along the 11 nes suggested by asset market approach. 
TABLE 7: The Weights of Imported Raw Materlals and Petroleum in the Domestic Price Bquation

\begin{tabular}{|c|c|c|}
\hline Market & Petroleum Prices & $\begin{array}{l}\text { (2) Import Prices } \\
\text { of Raw Materials }\end{array}$ \\
\hline 1. Australla & 0.018 & 0.101 \\
\hline 2. Anstria & 0.022 & 0.195 \\
\hline 3. Belglum-Luxembourg & 0.043 & 0.316 \\
\hline 4. Canada & 0.031 & 0.106 \\
\hline 5. Denmark & 0.028 & 0.226 \\
\hline 6. Finland & 0.045 & 0.197 \\
\hline 7. France & 0.047 & 0.130 \\
\hline 8. Germany & 0.030 & 0.157 \\
\hline 9. Iceland & 0.000 & 0.288 \\
\hline 10. Ireland & 0.033 & 0.332 \\
\hline 11. Italy & 0.066 & 0.168 \\
\hline 12. Japan & 0.063 & 0.102 \\
\hline 13. The Netherlands & 0.068 & 0.257 \\
\hline 14. Norway & 0.000 & 0.241 \\
\hline 15. Portugal & 0.055 & 0.266 \\
\hline 16. Spaln & 0.064 & 0.143 \\
\hline 17. Sweden & 0.021 & 0.176 \\
\hline 18. Switzerland & 0.010 & 0.177 \\
\hline 19. United Kingdom & 0.044 & 0.166 \\
\hline 20. Inited States & 0.019 & 0.040 \\
\hline 21. Greece & 0.109 & 0.241 \\
\hline 22. New Zealand & 0.018 & 0.101 \\
\hline 23. Turkey & 0.030 & 0.110 \\
\hline 24. Non-011 LDCs* & 0.000 & 0.000 \\
\hline 25. OPEC* & 0.000 & 0.000 \\
\hline 26. Centrally Planned Economlest & 0.000 & 0.000 \\
\hline
\end{tabular}

Source: See text.

*The data are not avallable for non-o1l LDCs, OPEC, and CPEs. 
the exchange rate equations were neglected $2 /$ due to the fact that our growth profections do not give any indiclation of the future monetary growth of these countries and only the effects coming through changes in net private forelgn asset stocks were taken into account.

Bxchange rate equations were estimated in $10 g$-form and that is why the obtained parameters are elasticlties. For our purpose these equations were translated into a linear form using the following procedure. The exchange rate equations can be written in elasticity form as:

$$
\frac{d E}{E}=\alpha^{l} \frac{d F^{l}}{F}-\alpha^{f} \frac{d F^{f}}{F^{f}}
$$

where:

$E=$ the exchange rate (forelgn currency/local currency).

$F=$ net private forelgn asset stock, subscript ${ }^{1}$ and $f$ refer to local and forelgn, respectively.

$\alpha=$ estimated elasticities; 1 and $f$ refer to local and forelgn respectively. multiplying by $E$ and rearranging we obtain

$$
d z=\underbrace{a^{l} \frac{E}{F^{1}}}_{\xi} d F-\underbrace{\alpha^{f} \frac{E}{F^{f}}}_{0} d F^{f}
$$

where $\xi$ and $O$ are the coefficients shown in Table 8 . To calculate these, 1975 values for $E$ and $F$ were used. Equation (11) is the equation for exchange rates for Canada, France, Germany, Italy, Japan and the United Kingdom used in the model.

2/ Thus implicitly we assume that the effects coming through changes in both countrles' money stocks cancel each other out. The work is in progress to allow exchange rates to respond to different growth rates of money stocks. 
TABLE 8: Effect of changes in the net private foreign asset atocks on the exchange rate.

\begin{tabular}{|c|c|c|}
\hline $\begin{array}{l}\text { Change in the } \\
\text { Exchange Rate }\end{array}$ & \multicolumn{2}{|c|}{$\begin{array}{l}\text { Change in the net private forelgn asset stock } \\
\text { (U.S. bill). }\end{array}$} \\
\hline & U.S. (dollars) & Local (dollars) \\
\hline$e\left(\frac{s}{D M}\right)$ & -.001201 & .001463 \\
\hline$e\left(\frac{\$}{Y E N}\right)$ & -.000001830 & .00003431 \\
\hline \multirow[t]{2}{*}{$e\left(\frac{\$}{\$ C A}\right)$} &.- .002150 & .001169 \\
\hline & Germany (dollars) & Local (dollars) \\
\hline$e\left(\frac{S}{E}\right)$ & -.02320 & .03268 \\
\hline$e\left(\frac{S}{\operatorname{LIRA}}\right)$ & -.000009880 & .000008414 \\
\hline$e\left(\frac{S}{F F}\right)$ & -.000432 & .001186 \\
\hline
\end{tabular}


1. Artus, J.R. and Rhomberg, R.R., 1973, A Mult1lateral Pxchange Rate Mode1, IMF Staff Papers, Vo1. XX No. 3, November.

2. Basev1, Georg10, 1973, Commodity Trade Equations in Project Link in Ball, R.J. (editor), The Intemational Linkage of National Economic Models, (Morth Holland, Amsterdam).

3. Branson, W.H., 1977, Asset Markets and Relative Prices in Exchange Rate Determination, Sozlalcuissiuschaftliche Annalsu, Band I.

4. Branson, W.R., Malttunen, H., 1978, Asset-Market Determination of Exchange Rates: Initial Fmpirical and Policy Results, forthconing in Martin, J.P., Smith, A., Trade and Payments Adjustment Onder Flexible Exchange Rates (MacMillan, London).

5. Branson, N.H., Halttunen, H., Masson, P., 1978, Bxchange Rates in the Short Run: The Dollar-Deutschemark Rate, forthcoming in European Economic Review.

6. Branson, W.H., Papaefstrat1ou, L., 1978, Income Instab1lity, Terms of Trade and the Change of Krchange Rate Reg1mes, Unpublished Paper.

7. Deppler, M.C., Rfpley, D.C., 1978, The World Trade Model: Merchandise Trade, MMF Staff Papers, Narch.

8. Dornbusch, R., Rrugman, P., 1976, Flextble Exchange Rates in the Short Run, Brookings Papers on Economic Activity, No. 3.

9. Houthakker, H.S., Magee, S.P., 1969, Income and Price Rlasticities in World Trade, Review of Economics and Stat1st1cs, II, May.

10. Jonson, P.D., But1in, M.W., 1977, Price and Quantity Responses to Monetary Impulses in a Model of a Small Open Bconomy, Research D1scussion Paper 7703, July, Reserve Bank of Australla.

11. Samuelson, L., 1973, A New Model of World Trade, ORCD Economic Outlook, Occasional Studies, December.

12. Stern, R.1., Francis, J., Schumacher, B., (editors), 1976, Price Blasticities in International Trade, (Macililan, London).

13. Taplin, G.B., 1973, A Model of World Trade in Ball, R.J. (editor), The International Linkage of National Economic Models, (North Holland, Ansterdam). 